\title{
TRANSFORMATION OF PESANTREN IN MAINTAINING GOOD CHARACTER
}

\author{
Muhammad Hifdil Islam* \& Abd. Aziz ${ }^{* *}$
}

Abstract: Education is the main pillar of nation building. The success of a nation's education is closely related to the progress achieved. Because it is a necessity, so the government and society should prioritize the overall development of the field of education. Especially education that shapes the national character of the nation. Pesantren as one of the indigenous Indonesian National Education sub-systems, has special advantages and characteristics in applying character education for their students (santri). The writing method this article is writer takes some of schoolars argument that related with the topic of this articel. "this article try to highlight the pesantren as the root of history of islamic education in Indonesia, the transformation of pesantren education system and the role of pesantren in Indonesia in maintaining the good character of student. And the result of this article show that pesantren has many types of system and it has a big role in maintaining the good character of student.

Keywords: Transformation, Pesantren and Good Character

\footnotetext{
* Dosen Institut Ilmu Keislaman Zainul Hasan Genggong

** Dosen Institut Ilmu Keislaman Zainul Hasan Genggong
} 


\section{PRELIMINARY}

Islamic boarding school is an institution that is widely praised by people. This is because the pesantren has a characteristic compared to other educational institutions, especially Muslim societies in general, as well as the existence of Madrasah (Schools that is based on islamic education) in Indonesia ${ }^{1}$. But at the same time often also get criticized and labeled as an institution that gives the barreir to the progress of Islam. Because of those controversies, pesantren becomes an institution which is always concerned. A positive outlook will place the controversy as an opportunity to strengthen the role of the pesantren itself. Madrasab as an part of pesantren managed by Ministry of Religion (Kementerian Agama) is still considered have low quality by some people. Along with the changes and developments of the times, advances in science and technology and globalization, efforts aimed at developing quality so that the image of this school does not always become number two, after other public schools, many things can be done by madrasa stakeholders.

In line with global developments, Islamic education faces fairly basic managerial challenges. Expectations from various parties for education to be managed in a "educational industry" pattern is one of the developments that have emerged in the current competitive era. Educational management can no longer be regarded as "social management" that is free from the necessity of achieving targets and is controlled by subjects with a "narrow" vision, for example with a familial approach such as the author encountered in most pesantren in Indonesia. Something that can be developed in the management of Islamic education such as pesantren, madrasa and Islamic schools is a strategic management pattern that can be defined as a set of decisions and actions that result in the formulation and implementation of plans to achieve company goals in terms of this is called madrasah. ${ }^{2}$

In the context of pesantren, madrasa and Islamic school education, if the application of "instructional management" is formulated in rigid practical patterns by policy holders, it will accumulate problem

1 Stanton, Charles Michael, Haiger. 1990." Learning in Islam, The Classical Period, A.D., 700-1.300," Rowman \& Littlefield Publisher, Inc.,

2 Agus Maulana. MSM dalam Pearce Robinson. 1997. "Manajemen Strategik, Formulasi, Implementasi dan Pengenalian.” Jakarta: Binarupa Aksara. hlm 66 
vulnerability. Such as inadequate learning process, unprofessional development of human resources (HR) and so on. Allowing this pattern to develop (without any alternative solution to the development of pesantren, madrasas and Islamic schools in the future) will in time threaten the existence of pesantren, madrasas and Islamic schools themselves. The most important of all in carrying out madrasa management, especially in its strategic role, is to reflect and evaluate all the potentials of stakeholders and then jointly develop programs and plans for the development of Islamic boarding schools, madrasas and schools gradually and reaffirm stakeholder commitment to the importance of Islamic education (madrasa) in order to prepare students who are intelligent, moral and have skills, so that they can contribute to the development of time thinking.

At a glance, if we pay attention, the era of globalization encountered by the community has in fact strengthened people's attention towards pesantren. Among the causes is possible because of the enthusiasm to seek alternative education. The global era seems to require a person or even the wider community to seek, explore and develop alternative education and at the same time to enlarge opportunities of excellence, especially those related to the role of Islamic boarding schools, Islamic schools and schools in Indonesia. In this paper the authors state the following points: 1) pesantren as the historical roots of Islamic education in Indonesia, 2) the existence of pesantren, Islamic schools and Islamic schools, 3) Reactualization of the strategic role of pesantren and Islamic schools.

\section{Pesantren as The Root of History of Islamic Education In Indonesia}

Talking about the historical roots of Islamic education in Indonesia cannot be separated from pesantren. Because the pesantren is considered an original Indonesian education system. ${ }^{3}$ however, other information proves that the pesantren education systemis an adaptation of the education system that was developed previously. One information says that, pesantren as stated in the first opinion is a continuation and refinement of pre-Islamic education practices or the period of Hindu Buddhist rule. Pesantren has an historical relationship with pre-Islamic educational

3 Amin Haedari. "Peran Strategis Pesantren, Madrasab dan Sekolab Islam di Indonesia." Jurnal Pondok Pesantren Mihrab, vol. II No. 1 Juli 2007, hlm 2 
institutions that have existed since the reign of Hindu Buddhism, then Islam continued and Islamized it. From the naming of pesantren itself is related to the terminology that exists in Hindu circles. The word pesantren is is originated from the word "santri" (means student) with the prefix "pe" and the suffix "an". According to opinion of C.C.Berg the term of santri is derived from the Indian word Shastri, meaning people who know and understand the sacred books of the Hindu Religion, or a scholar of the Hindu Religious scriptures. Furthermore, the word Shastri itself comes from the word shastra which means a holy books or knowledge books. The second opinion states that pesantren has historical relations with the Middle East. Associated with the influence of the Middle East is a lot that has proven especially moslem who perform the pilgrimage in Mecca and Medina. Mecca and Medina for Indonesian scholars are not only a place to perform the pilgrimage but a place to seek knowledge, especially by attending the recitation at the Masjdil Haram (The Grand Mosque) and Masjid Nabawi (The Prophet Mosque). This difference of opinion does not mean that one opinion is correct, while other opinions are wrong. These two opinions complement each other and the pesantren cannot be separated from the Hindu elements which had already existed in Indonesia and the elements of Islam of middle eastern where Islam originated. ${ }^{4}$

The roots of the history of pesantren cannot be separated from the history of the influence of Walisongo in the 15-16 century in Java. Pesantren is a unique Islamic educational institution in Indonesia. Walisongo is a propagator of Islam in Java in the 16th-15th century who has succeeded in combining secular and spiritual aspects in introducing Islam to the public. The uniqueness in question is that almost all pesantren in Indonesia in developing their pesantren education are oriented to the teachings of Walisongo. Whereas Maksum mentioned that the historical roots or origins of Islamic educational institutions such as pesantren or madrasah are in the fifth century Hijriyah. Pesantren arising in Islam, is not known in the days of friends and tabi' in, but something new after 400 years after the Hijriyah. ${ }^{5}$

${ }^{4}$ Dhofier, Z. 2011. "Tradisi Pesantren Studi Pandangan Hidup Kyai dan Visinya Mengenai Masa Depan Indonesia.” Jakarta: LP3ES. Hlm. 11

5 Maksum.1999. "Sejarah Madrasah dan Perkembangannya." Ciputat: PT Logas Wacana Ilmu. hlm 23 
Generally, pesantren starts from the presence of a kiai (leader of pesantren), then comes a santri who wants to study religion with him. After more and more students came, an initiative arose to establish a cottage or dormitory next to the kiai's house. In the past, the kiai only thought to teach religious knowledge in order to be understood and understood by students without planning how to build hut for santri. At that time the kiai did not give full attention to the places inhabited by the students. Student built a small house which is known as "pondok" around the kiai's house for living place. Then, because the number of students were increased, the more the huts were built. The existence of students make pesantren become popular and it became famous everywhere, for example as in the huts that arose during the Wali Songo era. ${ }^{6}$ Pesantren have big role in Indonesia either for the progress of Islam itself or for the Indonesian people as a whole. Based on the records, since 1596 religious education activities in the Indonesia had begun. These activities became known as pondok pesantren. Even in the notes of one of the Islamic scholars in Indonesia namely Howard M. Federspiel some pesantren in Indonesia have produced important writings and has attracted students to study such as in Dayah in Aceh (Dayah is local name of pesantren in Aceh), Palembang (Sumatra), East Java and in Gowa (Sulawesi). ${ }^{7}$

The development from pesantren to madrasa emerged in the early 20th century, as a result of dissatisfaction with the pesantren system (at that time) which was considered to be narrow and limited to the teaching only on "islamic studies". ${ }^{8}$ There were two factors underlying the growth of the pesantren system in Indonesia, the first being a factor Islamic reform and second response to the politics of education in the Dutch East Indies. The emergence and development of pesantren through madrasab can not be separated from the Islamic reform movement and then developed by Islamic organizations in Java. Therefore, education was seen as a strategic aspect in shaping the Islamic view of society. In reality, people saw the education of pesantren is too oriented towards the ubudiyyah

6 Hielmy, Irfan. 2000. “Wancana Islam.” Ciamis:Pusat Informasi Pesantren. Hlm. 120

7 Fatah, H Rohadi Abdul, Taufik, M Tata, Bisri, Abdul Mukti. 2005. "Rekontruksi Pesantren Masa Depan.” Jakarta Utara: PT. Listafariska Putra, 2005. Hlm. 11

8 Mas'ud Abdurrahman. 2002. "Dinamika Pesantren dan Madrasah." Yogyakarta: Pustaka Pelajar, hlm 45 
and religious aspect which is as shown in mosques, surau (small praying place) and seems to give less attention to social, political, economic and cultural issues. And because of that to pesantren need to be updated by renewing its education system. Most of scholar, agree that the related education system needs to be updated on an ongoing basis, based on this understanding education experts are taking steps towards improving the traditional education system towards a modern education system that is complemented by management patterns as quality standards. For the wider community, with the aim that the madrasa is not considered as one of the education that is "characterized" by traditional, so the tips to dismiss the community's assumption above are needed management organized in the modern education system.

\section{The Transformation of Pesantren Education System}

The curriculum is an important component as a reference for determining teaching content, directing the process of educational mechanisms, benchmarks of success and the quality of educational outcomes. The pesantren curriculum emphasizes more on religious studies and is based on classical books. The curriculum of pesantren is based on the level of ease and complexity of science or problems discussed in the book. In general, the pesantren system consists of 5 elements which constitute a unity which can not be separated, namely: ${ }^{9}$

1. Pondok as a hostel for students, gather and study at under the guidance of the kyai. The word pondok is composed with the word pesantren became a boarding school which is a form of institution Islamic education that is unique to Indonesia.

2. Mosque is a very important element in pesantren, because in this mosque is the central implementation of education under the care of the kyai.

3. Teaching classical or yellow books. The classic books taught in pesantren in general can be grouped into eight namely: Nahwu and sharaf, fiqh, ushul fiqh, Hadith, tafsir, monotheism, Sufism and other branches such as dates, balaghah and so on.

9 Masjkur.2007. "Integrasi Sekolab ke Dalam Sistem Pendidikan Pesantren." Surabaya: Diantama. Hlm. 19-20 
4. Santri, namely students who study religious sciences in boarding schools, both living in the cottage and returning home after completion study time. In other languages there are santri mukim who are santri come from distant areas and settle in boarding schools, and students of kalong are santri who come from areas around boarding schools usually they do not settle in boarding schools.

5. Kyai or leader of pesantren is a very essential element for a boarding school. The average pesantren that developed in Java and Madura was the figure of the kyai very influential, charismatic, authoritative, so highly respected by the community in the boarding school environment. $\mathrm{He}$ is a figure or a figure who becomes a central figure or inner role model pesantren environment. Besides being considered the highest leader, the kyai too considered as a source of learning by his students.

In general, the aim of the pesantren education system is to foster citizens to have Muslim personalities in accordance with the teachings of the Islamic religion and instill these religious feelings in all aspects of their lives and become them as useful people for religion, society and the country. While the specific objectives of a pesantren education system are (Masjkur, 2007: 21): ${ }^{10}$

1. Educate santri as members of the community to become good moslem

2. Obeying Allah. Having good morality, having intelligence, skill and being physically and spiritually born as citizens who has the philosophy of pancasila.

3. Educating students as cadres of ulama' (moslem scholar) and preachers who are sincere, steadfast, tough, self-employed in practicing islamic value as a whole and dynamically.

4. Educating students to gain personality and strengthen nationalism in order to foster development human beings who can build themselves and be responsible for national and state development.

Then, if pesantren is seen on the system, pesantren had transformed and it is divided into three types. Then, every types of pesantren has its own character, namely:

${ }^{10}$ Masjkur. 2007. "Integrasi Sekolah ke Dalam Sistem Pendidikan Pesantren." Surabaya: Diantama. Hlm. 21 
1. Traditional Pesantren / Salaf

This type of pesantren still retains to teach books which is written by scholars using Arabic language and it is called as kitab kuning. The pattern of teaching is by implementing the halaqah (student/santri surround the teacher/kiai) or mangaji (reading) which is carried out in the mosque. The teaching system emphasizes on memorization and the methodology tends to make students receive and possess knowledge. The given material of student is limited to what the kyai provide. The curriculum is entirely determined by the kyai caregivers of the cottage. ${ }^{11}$

2. Modern Pesantren

This type of pesantren develop new system education. The orientation of this system education tends to adopt the modern learning system and leave the traditional learning system. The application of modern learning systems is especially apparent in the use of classrooms learning both in the form of madrasas and schools. The curriculum of this pesantren used the national curriculum which is given by the government. ${ }^{12}$ The position of kyai is as the coordinator of the learning process and as teacher in the class. The portion of Islamic education and Arabic language is placed as a local curriculum.

3. Comprehensive Pesantren

The system of this pesantren is a combination of traditional and modern education and teaching system. Education is applied with the teaching of the yellow book (kitab kuning). Then, this pesantren uses method of sorongan, bandongan and wetonan in teaching kitab kuning and it is usually taught at night after the evening prayer and after the Fajr prayer. The classical system learning process is carried out in the morning until during the day like in madrasas / schools in general. ${ }^{13}$

${ }^{11}$ Muhammad Idris Usman. 2013. "Pesantren sebagai lembaga pendidikan islam (sejarah labir, sistem pendidikan dan perkembangannya masa kini).” Jurnal Al-Hikmah. UIN Alauddin Makassar. Vol. XIV No. 1. Hlm. 16

${ }^{12}$ M. Bahri Ghazali. 2001. "Pendidikan Pesantren Berwawasan Lingkungan: Kasus Pondok Pesantren An-Nuqayah Guluk-Guluk Sumenep Madura.” Jakarta: Pedoman Ilmu. Hlm. 14

${ }^{13}$ M. Bahri Ghazali. 2001. "Pendidikan Pesantren Berwawasan Lingkungan: Kasus Pondok Pesantren An-Nuqayah Guluk-Guluk Sumenep Madura.” Jakarta: Pedoman Ilmu. Hlm. 15 
While the methods or models and forms of learning that are normally used in the pesantren education system can be specified into three types, namely as follows: First: Sorogan. The word sorogan comes from the Javanese language which means "sodoran or offered". That is to say an individual learning system where a santri is dealing with a teacher, there is interaction between the two. A kyai faces santri one by one, in such a manner. Implementation, many students came together, then they queued waiting for their turn. Second: Bandungan. This method is often referred to as halaqah, where in the recitation, the books read by the kyai are only one, while the students carry the same book, then students listen and listen to the kyai's reading. Third: Weton. The term weton is derived from Javanese which is interpreted periodically or in time. Weton recitation is not a routine daily recitation, for example at a faithful completion of Friday prayers and besides. ${ }^{14}$

In addition to the three above, there are other methods applied in pesantren such as deliberation / bahtsul masa'il. This method is a learning method that is similar to the discussion method. Some students form halaqah which is led directly by kyai / ustadz to study a predetermined problem. There are also memorization methods (muhafazhah), demonstration / practice of ubudiyah, and so on. ${ }^{15}$

\section{The Role of Pesantren In Indonesia In Maintaining The Good Character Of Student}

Islamic boarding schools implement totality of education by relying on example. Environment creation and habituation through various tasks and activities. So that all what students see, hear, feel and do is education. Aside from making exemplary a primary educational method, miliu creation is also very important. That educational environment is what educates. The creation of the environment can be done through habituation, assignment, teaching, direction, training and exemplary.

Every component of pesantren can give influence in the formation of students' character. The assignment of these tasks is accompanied

${ }^{14}$ Hasbullah. 1996. "Kapita Selekta Pendidikan Islam. "Jakarta: PT. Remaja Grafindo Persada. Hlm. 50-52

${ }^{15}$ Masjkur.2007. "Integrasi Sekolab ke Dalam Sistem Pendidikan Pesantren." Surabaya: Diantama. Hlm. 27 
by an understanding of its philosophical foundations, so students will carry out various tasks with awareness. Activity in pesantren contains elements of education. For example, there is education in simplicity, independence, solidarity and togetherness, love for the environment and leadership in scouting activities. ${ }^{16}$ In addition, there is physical health education, planting sportsmanship, teamwork and persistence in trying In sports activities. The organization of activities in Islamic boarding school education is handled by Student Organizations which are divided into many sections, such as the Chair, Secretary, Treasurer, Security, Teaching, Information, Student Cooperative, Kitchen Cooperative, Student Canteen, Clean Circle, Gardening, Arts, Skills, Sports, Movers Language, etc.

This organizational education of pesantren is also for leadership regeneration through self-government education. Meanwhile at the dormitory level there is an organization of its own, consisting of the chairman of the dormitory, the security department, the mobilizer of languages, health, and the chair of the rooms. Each sports and arts club also has its own organizational structure. Moreover, there is an organizational which is based on the region of santri. All activities handled by these student organizations are escorted and guided by their seniors, consisting of the santri support staff, with the support of senior teachers who guide each activity. Directly the activities of caring for the students were taken care of by the leadership of the pesantren which is also the Caretaker of the pesantren. All pesantren rule should be based on the Al-Qur'an and hadits. and Hopefully, it will impact to the character of santri (student). ${ }^{17}$

These close, tiered and multi-level escorting is carried out by senior students and teachers, by carrying out supervisory and coaching tasks, in fact they are also going through a process of leadership education, because all students, especially senior students and teachers are cadres who are currently studying. The pesantren leaders fostered them through various approaches; program approach, humane (personal) approach the idealism

${ }^{16}$ Islam, M. H. (2019). Aplikasi Dan Diferensiasi Pendidikan Islam. Humanistika: Jurnal Keislaman, 5(1), 73-95.

${ }^{17}$ Islam, M. (2019). Model Pendekatan Halaqotul Mu`Allimin Al-Islamiyah dalam Membentuk Kepribadian Yang Rahmatan Lil Alamin Sebagai Identitas Kebangsaan di Pondok Pesantren Al-Mashduqiah. Proceedings of Annual Conference for Muslim Scholars, 3(1). 
approach and these approaches can be related to the multiculturalism approaches. ${ }^{18}$

They are also nurtured, guided, supported, directed, guarded, evaluated and improved. This is the character education implemented by pesantren through its various activities. Many activities will foster dynamic in order to form militancy and lead to work ethic and productivity. Eventually students will have a dynamic, active and productive personality in all goodness. The transformation of the values of pesantren education has been able to integrate all components of pesantren in one line. Untill then, there is no conflict of interests and orientation between one part and another. Every component of pesantren underlies steps with the value of sincerity, simplicity, sincerity and struggle to reach Allah's (God) pleasure. All have the understanding and calling for responsibility to realize the vision and mission of the pesantren education. All have an attachment to the system to the culture that has formed in the pesantren. Because they all have awareness and loyalty to values, systems and leaders. This solidity fosters tremendous strength in the process of character education in pesantren.

The concept of a good personality is found in the personality of rabmatan lil alamin and it can be seen in Islamic scholar thought. As we know that Islam as a religion respects human values, human rights and recognizes diversity. Then, multiculturalism in Islam is seen as Sunnatullah (God's Provisions) such as differences in color, race and ethnicity even if seen deeper, even though people have the same ethnicity and race, they also still have differences in gender, age, and geographical location, social and economic status and they are called diversity. Allah SWT created people in diversity to make them know each other, and to respect each other and it was written in Al-Qur'an Surah Al-Maidah verse 48 and that is the power in Surah Al-Hujurat verse 13. And one of the Prophetic traditions which reads:

${ }^{18}$ Islam, M. H. (2017). Diversity and Multicultural. Humanistika: Jurnal Keislaman, 3(1), 83-103. 


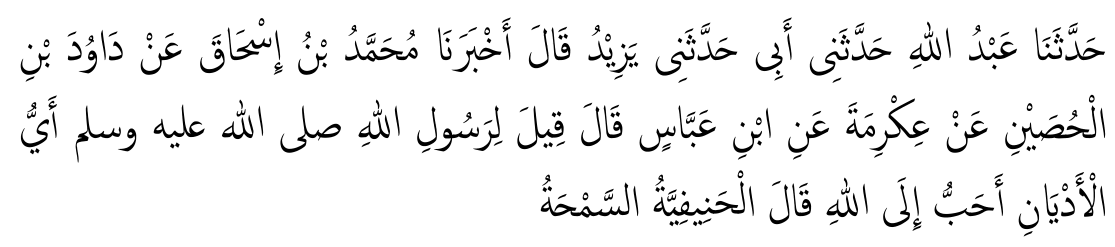

Meaning: "Has told us Abdillah, has told me Abi has told me Yazid, he said; has preached to us Muhammad bin Ishaq from Dawud bin Al Hushain from Ikrimah from Ibn 'Abbas, he said; Asked to the Messenger of Allah. "Which religion is most loved by God?" so he said: "Al-Hanifiyyah AsSambah (straight and tolerant)". ${ }^{19}$

\section{CONCLUSION}

At the end of this simple article, the writer hopes that the existence of pesantren, must be greater in line with the community's growing expectations, especially after other education has not been able to meet the mental and moral demands expected by the community. The pesantren starts by establishing the right vision and mission (goal), which is to produce cadres who are experts in the field of religion and qualified in social affairs, then together with the government to build partnerships to formulate policies and programs for developing pesantren, madrasas and Islamic schools in the future. Simple suggestions for example by referring to the standardized formal school quality system and industrybased managerial aspects (while still referring to the Qur'anic Hadith).

${ }^{19}$ A.Y Wensinck dan Muhammad Fuad 'Abd al-Baqi, al-Mu'jam al-Mufahras Li al-Faz al- Hadis al-Nabawi (Leden: E. J Brill), Juz. 1 h. 408. 


\section{REFERENCE}

Agus Maulana,MSM dalam Pearce Robinson. 1997. "Manajemen Strategik, Formulasi, Implementasi dan Pengenalan”. Jakarta: Binarupa Aksara.

Amin Haedari. "Peran Strategis Pesantren, Madrasah dan Sekolab Islam di Indonesia." Jurnal Pondok Pesantren Mihrab, vol. II No. 1 Juli 2007

A.Y Wensinck dan Muhammad Fuad 'Abd al-Baqi, "al-Mu'jam alMufahras Li al-Faz al-Hadis al-Nabawi” (Leden: E. J Brill), Juz. 1 h. 408.

Dhofier, Z. 2011. "Tradisi Pesantren Studi Pandangan Hidup Kyai dan Visinya Mengenai Masa Depan Indonesia”. Jakarta: LP3ES.

Fatah, H Rohadi Abdul, Taufik, M Tata, Bisri, Abdul Mukti. 2005. "Rekontruksi Pesantren Masa Depan". Jakarta Utara: PT. Listafariska Putra, 2005.

Hasbullah. 1996. “Kapita Selekta Pendidikan Islam.” Jakarta: PT. Remaja Grafindo Persada.

Hielmy, Irfan. 2000. “Wacana Islam”. Ciamis:Pusat Informasi Pesantren.

Islam, M. (2019). Model Pendekatan Halaqotul Mu`Allimin Al-Islamiyah dalam Membentuk Kepribadian Yang Rabmatan Lil Alamin Sebagai Identitas Kebangsaan di Pondok Pesantren Al-Mashduqiah. Proceedings of Annual Conference for Muslim Scholars, 3(1).

Islam, M. H. (2017). Diversity and Multicultural. Humanistika: Jurnal Keislaman, 3(1), 83-103.

Islam, M. H. (2019). Aplikasi Dan Diferensiasi Pendidikan Islam. Humanistika: Jurnal Keislaman, 5(1), 73-95.

M. Bahri Ghazali. 2001. "Pendidikan Pesantren Berwawasan Lingkungan: Kasus Pondok Pesantren An-Nuqayah Guluk-Guluk Sumenep Madura." Jakarta: Pedoman Ilmu.

Maksum.1999. "Sejarah Madrasah dan Perkembangannya". Ciputat: PT Logas Wacana Ilmu.

Mas'ud Abdurrahman. 2002. "Dinamika Pesantren dan Madrasab". Yogyakarta: Pustaka Pelajar. 
Masjkur.2007. "Integrasi Sekolab ke Dalam Sistem Pendidikan Pesantren". Surabaya: Diantama.

Muhammad Idris Usman. 2013. "Pesantren sebagai lembaga pendidikan islam (sejarah labir, sistem pendidikan dan perkembangannya masa kini)". Jurnal Al-Hikmah. UIN Alauddin Makassar. Vol. XIV No. 1. Hlm. 16

Stanton, Charles Michael. 1990. "Haiger Learning in Islam, The Classical Period, A.D., 700-1.300”. Rowman \& Littlefield Publisher, Inc. 